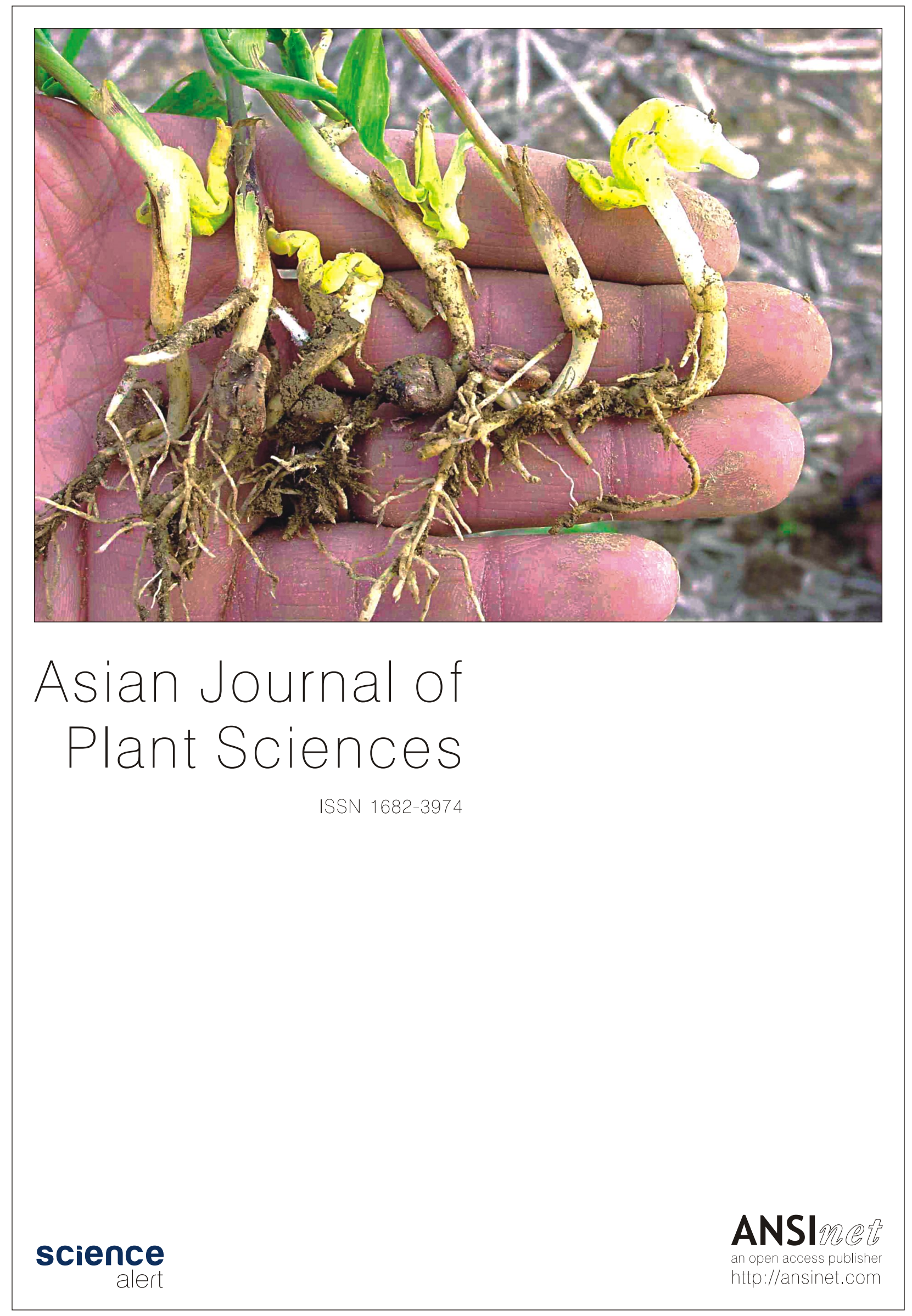




\title{
Bioprospecting Opportunities of Mangrove Fruits for the Coastal Community in Lubuk Kertang and Pulau Sembilan, North Sumatra, Indonesia
}

\author{
${ }^{1}$ Maulida Khairiza Nawar, ${ }^{2,3}$ Mohammad Basyuni, ${ }^{1}$ Chairani Hanum and ${ }^{4}$ Etti Sartina Siregar \\ 1 Magister Program of Agrotechnology, Faculty of Agriculture, Universitas Sumatera Utara, Medan 20155, Indonesia \\ ${ }^{2}$ Center of Excellence for Mangrove, Universitas Sumatera Utara, Medan 20155, Indonesia \\ ${ }^{3}$ Department of Forestry, Faculty of Forestry, Universitas Sumatera Utara, Medan 20155, Indonesia \\ ${ }^{4}$ Department of Biology, Faculty of Mathematics and Natural Sciences, Universitas Sumatera Utara, Medan 20155, Indonesia
}

\section{Abstract}

Background and Objective: Mangrove plants are known sources of food and medicinal ingredients. Mangroves in Lubuk-Kertang, Pulau-Sembilan, Langkat and North Sumatra, Indonesia have great biodiversity. The study purposed to evaluate nutritional parameters based on antioxidant content and elemental analysis (micronutrients and macronutrients) in 15 true and associated mangrove species in Lubuk Kertang and Pulau Sembilan mangrove forests of North Sumatra, Indonesia. Materials and Methods: Determining each bioprospection parameter based on nutrients, antioxidants and analysis elements (macronutrients and micronutrients) in fine fifteen mangrove fruits with three individual repetitions: A. auriculiformis, B. asiatica, C. equisetifolia, H. tiliaceus, L. littorea, L. racemosa, M. candidum, M. citrifolia, N. Fruticans, P. odoratissima, P. pinnata, S. hydrophyllacea, S. portulacastrum, S. jamaicensis and T. catappa. Each mangrove fruit was then labelled, stored in an icebox and taken to the laboratory. The data are presented as Mean $\pm S D$, using one-way analysis of variance (ANOVA), followed by pairwise comparisons using Fisher's Least Significant Difference (LSD), with the value of $\mathrm{p}<0.05$ as a significant limit. Results: The seventh nutritional parameter showed that $A$. auriculiformis had the highest protein content, $P$. pinnata had the highest fat content and $P$. odoratissima was the highest in two parameters (total sugar and non-reducing sugar). M. citrifolia provided the highest reducing sugar parameters of which $B$. asiatica and $L$. littorea were the highest for one parameter (moisture content and ash content). The highest antioxidant content of $P$. odoratissima as ascorbic acid. The highest beta-carotene was in $M$. candidum. The highest phenolic acid was in B. asiatica. The highest macronutrients varied among mangrove fruit species, sodium in L. racemosa, potassium in $N$. fruticans and calcium in $S$. jamaicensis. Further, the analysis of the highest microelements in iron was done in S. Portulacastrum and Manganese and copper in $H$. tiliaceus. Conclusion: This study showed that mangrove fruit has good prospecting value for antioxidants and-nutrients and is an alternative food source too for coastal communities.

Key words: Antioxidant, coastal community, element value, mangroves, nutritional value

Citation: Nawar, M.K., M. Basyuni, C. Hanum and E.S. Siregar, 2022. Bioprospecting opportunities of mangrove fruits for the coastal community in Lubuk Kertang and Pulau Sembilan, North Sumatra, Indonesia. Asian J. Plant Sci., 21: 145-153.

Corresponding Author: Mohammad Basyuni, Center of Excellence for Mangrove, Universitas Sumatera Utara, Medan 20155, Indonesia Department of Forestry, Faculty of Forestry, Universitas Sumatera Utara, Medan 20155, Indonesia

Copyright: @ 2022 Maulida Khairiza Nawar et al. This is an open access article distributed under the terms of the creative commons attribution License, which permits unrestricted use, distribution and reproduction in any medium, provided the original author and source are credited.

Competing Interest: The authors have declared that no competing interest exists. 


\section{INTRODUCTION}

Mangroves are defined as halophytic woody plant communities along tropical and subtropical coastlines'. According to another study ${ }^{2}$, mangroves are divided into major mangroves and minor mangroves, while other species found around the mangrove ecosystem are known as associated mangroves ${ }^{3}$.

Mangroves are biochemically unique plants, due to their diverse secondary metabolite content ${ }^{4}$. Some types of mangroves can be used as food and medicine ${ }^{5}$. Producers of carbohydrates, o-methyl-inositol, sugars, iridoid glycosides, free amino acids, pheromones, gibberellins, phorbol, esters, heterocyclic oxygen, sulfur compounds, fats, free fatty acids $^{6}$. In addition, the leaves and roots of plants also contain polyphenolic compounds, minerals, vitamins and amino acids ${ }^{7}$.

Mangroves in Lubuk Kertang, Langkat and North Sumatra, Indonesia have the highest plant diversity: where found 15 true mangrove species ${ }^{8}$, while 26 species of associated mangrove were found in Pulau Sembilan?. Bioprospecting is defined as the exploration of bioresource materials and their conversion into derivative products that help conserve and utilize mangrove forests in a sustainable manner, such that it has little impact on natural regeneration and provides alternative food sources ${ }^{8}$. The use of mangroves for bioprospecting can serve as a food resource, as fruit and leaves can be used as a source of food and nutrition ${ }^{10}$ and as food and beverage like taffy, syrup, salad, cake and chip ${ }^{11}$.

The sustainable use of mangrove fruits will have little impact on natural regeneration and its role as an alternative food source. It also minimizes the conversion of mangroves to other land uses by providing coastal communities with an excellent alternative income source.

Bioprospecting was known to yield bioresource materials to produce commercially valuable, useful mangrove products and towards sustainable management of the mangrove ecosystem in Lubuk Kertang and Pulau Sembilan, North Sumatera, Indonesia. Many studies have examined the efficacy and usefulness of consuming mangrove products, but information about the antioxidant potential and nutritional value of North Sumatran mangroves is still lacking, though antioxidants play an important role in plant adaptation to abiotic and biotic stresses ${ }^{12}$. This study aimed to evaluate nutritional parameters based on bioprospection, antioxidant content and elemental analysis (micronutrients and macronutrients) in 15 true and associated mangrove species in Lubuk Kertang and Pulau Sembilan mangrove forests of North Sumatra, Indonesia.

\section{MATERIALS AND METHODS}

Study site: The research was conducted for seven months, namely from September, 2020 to April, 2021. Lubuk Kertang is located at Langkat Regency, Berandan Barat district, bounded on the East by Malacca Strait and South by Perlis district and Pangkalan Batu ( $4^{\circ} 03^{\prime} \mathrm{LU}$ and $98^{\circ} 16$ 16'00. 19" BT). Pulau Sembilan is located at Langkat Regency, Pangkalan Susu district and bounded on the East by Malacca Strait, South by Pangkalan Susu, West by Teluk Arun, and North by Pulau Kampai Strait $\left(04^{\circ} 08^{\prime} 39.13^{\prime \prime} \mathrm{N}\right.$ and $\left.98^{\circ} 13^{\prime} 55.38^{\prime \prime} \mathrm{E}\right)$. Another study ${ }^{8}$ found 15 species of mangrove families in Lubuk Kertang and 26 species of associated mangrove in Pulau Sembilan 9. Knowing that the mangroves in this area have high diversity, the local community works as fishermen, catching fish, crabs and prawns close together in the mangrove plants. The local community in this village can take advantage of the mangrove fruits as a potential source of food and medicine.

Sampling and mangrove fruit preparation: Fifteen selected mangrove fruits were selected, consisting first of four major mangrove fruits: Lumnitzera littorea(Jack.), (Combretaceae), Lumnitzera racemosa Willd (Combretaceae), Nypa fruticans (Thunb.) Wurmb. (Araceae), Scyphiphora hydrophyllacea Gaertn. F. (Rubiaceae). Eleven others from associated mangroves namely, Barringtonia asiatica (L.), Kutz (Lecythidaceae), Pandanus odoratatissima (L.) F. (Pandanaceae), Stachytarpheta jamaicensis (L.) Vahl (Verbenaceae), Casuarina equisetifolia L (Casuarinaceae), Melastoma candidum (D.) Don (Melastomaceae), Morinda citrifolia L. (Rubiceae), Sesuvium portulacastrum L. (Alzoaceae), Terminalia catappa L. (Combretaceae), Acacia auriculiformis (A.) Cun. ex-benth. (Mimosoidae), Hibiscus tiliaceus L. (Malvaceae) and Pongamia pinnata (L.) Pierre. (Leguminosae) were collected on September-October, 2020. The flow chart of the implementation of bioprospecting and functional food from selected mangrove fruits is described in Fig. 1.

These mangrove species produce fruits at approximately the same time. B. asiatica, M. citrifolia, $T$. catappa and $H$. tiliaceus were found on the banks and along with the river mouth in Lubuk Kertang. $P$. odoratatissima was found along the mangrove coast, while C. equisetifolia, A. auriculiformis, S. jamaicensis, M. candidum, S. hydrophyllacea, S. portulacastrum, P. pinata, $N$. fruticans, $L$. racemosa and L. littorea were found mostly along the upstream estuary. 


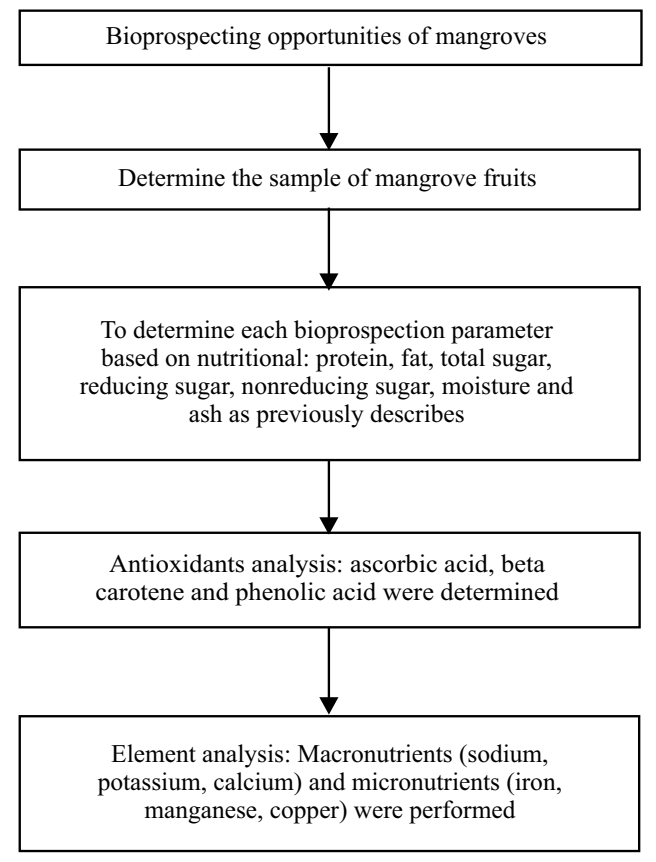

Fig. 1: Flow chart of bioprospecting functional food from selected mangrove fruits

Three individuals were taken from each mangrove species. Mangrove fruit in decent condition and without damage was then collected for further analysis. Each mangrove fruit was then labelled, stored in an icebox and taken to the Tjut Nyak Dhien University Research Laboratory for antioxidant analysis, to the Medan Research and Industrial Standardization Institute for nutrient content analysis, and the Socfindo Laboratory Medan for elemental analysis (macronutrients and macronutrients). Upon arrival at the laboratory, some samples were separated for drying and others were analyzed in a fresh condition. All samples were dried in an oven for 3 days at $100^{\circ} \mathrm{C}$ and used for elemental analysis.

Total protein etraction and estimation: Approximately $500 \mathrm{mg}$ of mangrove fruit samples were put into a $100 \mathrm{~mL}$ flask using the Kjeldahl Semi micro Method, adding $2 \mathrm{~g}$ of the selen mixture and $25 \mathrm{~mL}$ of concentrated $\mathrm{H}_{2} \mathrm{SO}_{4}$ and heated on a hotplate until it boiled and the solution became clear greenish (about 2 hrs). It was allowed to cool, diluted and put into a $100 \mathrm{~mL}$ volumetric flask, aligning to the line mark. The $5 \mathrm{~mL}$ of the solution was put in a Pipette and placed in a distiller and $5 \mathrm{~mL}$ of $30 \%$ $\mathrm{NaOH}$ and a few drops of PP indicator were added. The samples were distilled for about $10 \mathrm{~min}$ in a container using $10 \mathrm{~mL}$ of $2 \%$ boric acid solution. The tip of the cooler was rinsed with distilled water, Titar with $0.01 \mathrm{~N} \mathrm{HCl}$ solution. Blank determination was performed.

Fat content extraction and estimation: The fat content of the mangrove fruit was extracted using the direct extraction method with the Soxhlet tool. Two gram of the fruit sample was weighed and put it in a paper sleeve lined with cotton. The paper sleeve containing the sample was plugged with cotton, heated in the oven at a temperature of not more than $80^{\circ} \mathrm{C}$ for $1 \mathrm{~h}$ and put in a Soxhlet connected to a fat flask containing boiling stones that had been dried and had known weight. The contents were extracted with hexane or another fat solvent for approximately $6 \mathrm{hrs}$. Hexane was distilled and the fat extract dried in a drying oven at $105^{\circ} \mathrm{C}$, cooled and weighed. This drying was repeated until a constant weight was reached.

Total sugar extraction and estimation: The total sugar content of 15 mangroves was ascertained through the Luff Schoorl method. The $50 \mathrm{~mL}$ Pipette was filtered into a $100 \mathrm{~mL}$ flask. Twenty-five $\mathrm{mL}$ of $25 \% \mathrm{HCl}$ was added and the contents hydrolysed. This was followed by the addition of $40 \% \mathrm{NaOH}$ indicator PP until it turned pink. Aquadest was added and the contents were shaken up to 12 times. Ten $\mathrm{mL}$ was Pipetted into a $500 \mathrm{~mL}$ Erlenmeyer, $15 \mathrm{~mL}$ of aquadest and add $25 \mathrm{~mL}$ of Luff's solution were added, following by the addition of the boiling stones. After boiling for $10 \mathrm{~min}$, the contents were allowed to cool. Ten $\mathrm{mL}$ of $20 \% \mathrm{HCl}$ and $25 \mathrm{~mL}$ of $25 \% \mathrm{H}_{2} \mathrm{SO}_{4}$ were added. The $0.1 \mathrm{~N} \mathrm{Na}_{2} \mathrm{~S}_{2} \mathrm{O}_{3}$ solution was titrated twice until the colour changed to rice white.

Reducing sugar extraction and estimation: Reducing sugar was calculated in fifteen mangroves using the Luff Schoorl method. Take $10 \mathrm{~mL}$ of the filter and put it in a $500 \mathrm{~mL}$ Erlenmeyer. Fifteen $\mathrm{mL}$ of aquadest was added to $25 \mathrm{~mL}$ of Luff's solution, with boiling stones, heated for $10 \mathrm{~min}$ and cooled. The $25 \mathrm{~mL}$ of $25 \% \mathrm{H}_{2} \mathrm{SO}_{4}$ and Ten $\mathrm{mL}$ of $20 \% \mathrm{Hcl}$ were added titrated with $0.1 \mathrm{~N} \mathrm{Na}_{2} \mathrm{~S}_{2} \mathrm{O}_{3}$ and titrated again until the colour changed to rice white.

Non-Reducing sugar estimation and extraction: Nonreducing sugars were quantified using subtracting amounts to reduce the sugar from the total sugar.

Proximate analysis: Fifteen mangrove fruit extracts $(5 \mathrm{~g})$ were weighed and used to measure the moisture content using a moisture analyzer MX-50 (A and D Company Ltd.) at $115^{\circ} \mathrm{C}$. An empty, clean evaporated dish was heated for $1 \mathrm{~h}$ to the furnace of muffle at $600^{\circ} \mathrm{C}$ to determine the amount of ash content of eight mangrove fruits ${ }^{13}$. The resulted ash was 
then cooled and stored in a desiccator and weighed as W1. As much as $1 \mathrm{~g}$ of each fruits samples was stored in an evaporating dish (W2). The sample was burned for $6 \mathrm{hrs}$ in a furnace of muffle at $550^{\circ} \mathrm{C}$ till charred. Grey-white ash will produce when all organic matters of the sample were oxidized. The evaporated cooling dish was described in weighed (W3). The percent ash calculation was determined using the formula:

$$
\text { Ash }(\%)=\frac{\text { Weight ash difference }}{\text { Weight sample initial }} \times 100
$$

The weight ash difference $=$ W3 - W1 .

Where:

W1 = Weight of the empty evaporated dish

W2 = The initial sample weight

W3 = Final weight of the evaporating dish and initial weight of the sample from the furnace

\section{Estimation and extraction of ascorbic acid content:}

Ascorbic acid content was measured based on the literature ${ }^{13}$ with some modifications. Mangrove fruit was extracted with $0.5 \%$ oxalic acid solvent, $10 \mathrm{~mL}$ of the filtrate was filtered and $1 \mathrm{~mL}$ of $500 \mathrm{~g} \mathrm{~mL}^{-1}$ Potassium Permanganate $\left(\mathrm{KMnO}_{4}\right)$ reagent was added, homogenized. The absorption at $\lambda$ maximum $525.5 \mathrm{~nm}$ was measured immediately (UV/Vis UV1800 Spectrophotometer). The concentration of ascorbic acid was calculated using the linear regression equation of the

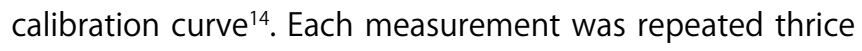
and the ascorbic acid content was calculated using a standard curve and expressed as $\mathrm{mg} / 100 \mathrm{~g}$ fresh weight.

Carotenoids content extraction and estimation: Total carotenoids content was counted by using sample compared with the standard of $\beta$-carotene ${ }^{15}$. Approximately $0.5 \mathrm{~g}$ of sample powder from each mangrove fruit was weighed and homogenized with $80 \%$ acetone. The volume of the solution was then brought to $50 \mathrm{~mL}$ and centrifuged at 5,000 rpm for $20 \mathrm{~min}$ until the supernatant became transparent. The supernatant was taken and absorbance was measured at 645 and $663 \mathrm{~nm}$ (UV/Vis-1280 Spectrophotometer).

Total phenolic content analysis: The total phenolic content was measured based on the literature ${ }^{16}$. Mangrove fruit was extracted with distilled water and then filtered. A total of 100.1 of the filtrate was added with 100.1 of Folin-Ciocalteu reagent (1:1) and $1 \mathrm{~mL}$ of $7.5 \% \mathrm{Na}_{2} \mathrm{CO}_{3}$ into a test tube. The mixture was homogenized with a vortex and allowed to stand for $120 \mathrm{~min}$. Then $3.8 \mathrm{~mL}$ of Aqua pro-injection was added and the absorbance was measured at a wavelength of $727.5 \mathrm{~nm}$ (UV/Vis UV-1800 Spectrophotometer). Each measurement was repeated thrice and the result was expressed as $\mathrm{mg}$ gallic acid equivalent (GAE)/100 $\mathrm{g}$ fresh weight $^{16}$.

Macronutrient analysis: Macronutrients such as sodium ( $\mathrm{Na}$ ), potassium ( $\mathrm{K}$ ) and calcium ( $\mathrm{Ca}$ ) from fifteen mangroves were analyzed ${ }^{17}$. About $0.5 \mathrm{~g}$ finely powdered samples of each mangrove fruit were digested using $30 \% \mathrm{H}_{2} \mathrm{O}_{2}$ and $\mathrm{HNO}_{3}$ concentrated. Digested samples were used for $\mathrm{Na}, \mathrm{K}$ and $\mathrm{Ca}$ analysis using a PFP7 flame photometer (Jenway, Staffordshire, UK). Each sample was measured in three trials.

Micronutrient analysis: Micronutrients were analysed in fifteen mangroves ${ }^{17}$. Approximately $0.5 \mathrm{~g}$ of finely ground mangrove fruits were wet digested using concentrated $\mathrm{HNO}_{3}$ and $30 \% \mathrm{H}_{2} \mathrm{O}_{2}$. The digested samples were then analyzed for Iron (Fe), Manganese $(\mathrm{Mn})$, Copper $(\mathrm{Cu})$ concentrated using flame atomic absorption spectrophotometer, processed in distilled water were processed as described above and used for a new solution. Each sample was measured in three trials.

Statistical analysis: The data are presented as Mean \pm Standard Deviation (SD) values for given and observation number, $\mathrm{n}=3$. The mean of nutritional, antioxidants, macronutrients and micronutrients (element analysis) values was calculated and statistically compared among mangrove fruits using one-way analysis of variance (ANOVA), followed by pairwise comparisons using Fisher's Least Significant Difference (LSD), with the value of $p<0.05$ as a significant limit. All statistical comparisons were calculated using the SPSS version 21 program.

\section{RESULTS}

Nutritional and proximal analysis: Comparative evaluation of the nutritional potential of fifteen selected mangroves, namely $A$. auriculiformis, B. asiatica, C. equisetofolia, H. tiliaceus, L. littorea, L. racemosa, M. candidum, M. citrifolia, N. fruticans, P. odoratissima, P. pinnata, S. hydrophyllacea, $S$. portulacastrum, $S$. jamaicensis and $T$. caappa was performed with various parameters such as protein, water content, total sugar, reducing sugar, non-reducing sugar and 
Asian J. Plant Sci., 21 (1): 145-153, 2022

Table 1: Comparative results of nutritional parameters from mangrove fruits in Lubuk Kertang and Pulau Sembilan, Sumatera Utara Indonesia

\begin{tabular}{|c|c|c|c|c|c|c|c|}
\hline \multirow[b]{2}{*}{ Species } & \multicolumn{7}{|c|}{ Nutritional parameters from mangrove fruits } \\
\hline & $\begin{array}{l}\text { Protein } \\
\left(\mathrm{mg} \mathrm{g}^{-1}\right)\end{array}$ & Fat $\left(\mathrm{mg} \mathrm{g}^{-1}\right)$ & $\begin{array}{l}\text { Total sugar } \\
\left(\mathrm{mg} \mathrm{g}^{-1}\right)\end{array}$ & $\begin{array}{l}\text { Reducing sugar } \\
\qquad\left(\mathrm{mg} \mathrm{g}^{-1}\right)\end{array}$ & $\begin{array}{l}\text { Non-reducing } \\
\text { sugar }\left(\mathrm{mg} \mathrm{g}^{-1}\right)\end{array}$ & Moisture (\%) & Ash (\%) \\
\hline A. auriculiformis & $43.88 \pm 0.09^{\mathrm{a}}$ & $8.77 \pm 0.26^{b}$ & $1.02 \pm 0.06^{i}$ & $0.01 \pm 0.00^{\mathrm{g}}$ & $1.02 \pm 0.06^{\mathrm{hi}}$ & $62.18 \pm 0.81^{\mathrm{hij}}$ & $1.53 \pm 0.01^{\mathrm{e}}$ \\
\hline B. asiatica & $17.49 \pm 0.07^{9}$ & $1.17 \pm 0.20^{\mathrm{i}}$ & $5.72 \pm 0.35^{f}$ & $1.61 \pm 0.08^{\mathrm{e}}$ & $4.10 \pm 0.41^{d}$ & $93.13 \pm 0.11^{\mathrm{a}}$ & $0.61 \pm 0.01^{i}$ \\
\hline C. equisetifolia & $20.21 \pm 0.09^{f}$ & $5.48 \pm 0.16^{f}$ & $3.16 \pm 0.23^{9}$ & $0.60 \pm 0.09^{f}$ & $2.55 \pm 0.33^{\mathrm{efg}}$ & $55.91 \pm 0.20^{k}$ & $0.29 \pm 0.01^{\mathrm{j}}$ \\
\hline H. tiliaceus & $32.06 \pm 0.16^{\mathrm{b}}$ & $1.96 \pm 0.09^{h}$ & $2.14 \pm 0.06^{h}$ & $0.01 \pm 0.00^{\mathrm{g}}$ & $2.14 \pm 0.06^{\mathrm{fgh}}$ & $63.91 \pm 3.23^{h}$ & $1.56 \pm 0.01^{\mathrm{e}}$ \\
\hline L. littorea & $17.34 \pm 0.12^{\mathrm{g}}$ & $8.16 \pm 0.17^{c}$ & $3.33 \pm 0.07^{9}$ & $0.01 \pm 0.00^{\mathrm{g}}$ & $3.33 \pm 0.07^{\mathrm{de}}$ & $59.28 \pm 1.05^{\mathrm{jk}}$ & $3.41 \pm 0.01^{\mathrm{a}}$ \\
\hline L. racemosa & $17.48 \pm 0.16^{9}$ & $4.33 \pm 0.10^{g}$ & $5.67 \pm 0.16^{f}$ & $2.85 \pm 0.11^{\mathrm{d}}$ & $2.82 \pm 0.05^{\mathrm{ef}}$ & $73.36 \pm 2.19^{e f}$ & $3.01 \pm 0.01^{b}$ \\
\hline M. candidum & $3.07 \pm 0.22^{k}$ & $4.59 \pm 0.06^{9}$ & $2.59 \pm 0.34^{g h}$ & $0.01 \pm 0.00^{g}$ & $2.59 \pm 0.34^{\mathrm{efg}}$ & $74.58 \pm 1.09^{\mathrm{def}}$ & $1.72 \pm 0.01^{\circ}$ \\
\hline M. citrifolia & $16.74 \pm 0.09^{\mathrm{h}}$ & $6.50 \pm 0.13^{e}$ & $19.58 \pm 0.16^{b}$ & $18.23 \pm 0.08^{\mathrm{a}}$ & $1.34 \pm 0.10^{\mathrm{hi}}$ & $86.30 \pm 0.14^{b}$ & $0.63 \pm 0.01^{i}$ \\
\hline N. fruticans & $20.66 \pm 0.47^{f}$ & $4.38 \pm 0.08^{g}$ & $6.76 \pm 0.03^{e}$ & $5.15 \pm 0.14^{b}$ & $1.61 \pm 0.13^{g h i}$ & $77.89 \pm 0.93^{c d}$ & $1.72 \pm 0.02^{\mathrm{d}}$ \\
\hline P. odoratatissima & $8.73 \pm 0.21^{j}$ & $7.09 \pm 0.14^{d}$ & $23.43 \pm 0.71^{\mathrm{a}}$ & $5.18 \pm 0.25^{b}$ & $18.24 \pm 0.93^{\mathrm{a}}$ & $59.66 \pm 0.84^{\mathrm{jk} k}$ & $1.28 \pm 0.01^{9}$ \\
\hline P. pinnata & $29.46 \pm 0.09 c$ & $26.45 \pm 0.16^{\mathrm{a}}$ & $1.06 \pm 0.01^{i}$ & $0.01 \pm 0.00^{\mathrm{g}}$ & $1.06 \pm 0.01^{\mathrm{hi}}$ & $69.06 \pm 1.54^{9}$ & $1.43 \pm 0.01^{f}$ \\
\hline S. hydrophyllacea & $14.36 \pm 0.19^{i}$ & $8.51 \pm 0.08^{b c}$ & $16.36 \pm 0.51^{c}$ & $1.58 \pm 0.34^{\mathrm{e}}$ & $14.77 \pm 0.83^{c}$ & $63.68 \pm 0.66^{\mathrm{hi}}$ & $2.02 \pm 0.01^{c}$ \\
\hline S. portulacstrum & $22.01 \pm 0.13^{e}$ & $7.25 \pm 0.14^{d}$ & $16.62 \pm 0.10^{c}$ & $0.01 \pm 0.00^{g}$ & $16.62 \pm 0.10^{\mathrm{b}}$ & $80.98 \pm 1.12^{c}$ & $3.37 \pm 0.01^{\mathrm{a}}$ \\
\hline S. jamaicensis & $23.01 \pm 0.08^{\mathrm{d}}$ & $6.54 \pm 0.11^{\mathrm{e}}$ & $8.51 \pm 0.27^{d}$ & $4.25 \pm 0.13^{c}$ & $4.25 \pm 0.13^{d}$ & $76.51 \pm 1.15^{\mathrm{de}}$ & $1.39 \pm 0.01^{f}$ \\
\hline T. catappa & $23.43 \pm 0.10^{d}$ & $8.52 \pm 0.09^{b c}$ & $1.02 \pm 0.09^{i}$ & $0.01 \pm 0.00^{g}$ & $1.02 \pm 0.09^{i}$ & $71.30 \pm 2.04^{\mathrm{fg}}$ & $1.07 \pm 0.01^{\mathrm{h}}$ \\
\hline
\end{tabular}

Data are expressed as Mean $\pm S D(n=3)$, means by the same superscript were not significantly different from each other $(p<0.05)$ by Fisher's LSD

Table 2: Comparative results of antioxidant parameters from mangrove fruits in Lubuk Kertang and Pulau Sembilan, Sumatera Utara Indonesia

\begin{tabular}{|c|c|c|c|}
\hline \multirow[b]{2}{*}{ Species } & \multicolumn{3}{|c|}{ Antioxidant contents from mangrove fruits } \\
\hline & Ascorbic acid (mg/100g) & Beta carotene $(\mathrm{mg} / 100 \mathrm{~g})$ & Phenolic acid (mg/100 g) \\
\hline A. auriculiformis & $8.21 \pm 1.50^{\text {cd }}$ & $16.85 \pm 0.86^{b}$ & $23.53 \pm 1.62^{\text {cd }}$ \\
\hline B. asiatica & $14.35 \pm 0.51^{\mathrm{ab}}$ & $10.10 \pm 0.84^{\text {defg }}$ & $103.69 \pm 8.95^{\mathrm{a}}$ \\
\hline C. equisetifolia & $15.33 \pm 1.15^{\mathrm{ab}}$ & $6.11 \pm 0.86^{\text {efgh }}$ & $34.53 \pm 1.69^{b}$ \\
\hline H. tiliaceus & $16.28 \pm 0.17^{\mathrm{a}}$ & $5.92 \pm 0.47^{\mathrm{fgh}}$ & $0.98 \pm 0.22^{f}$ \\
\hline L. littorea & $16.03 \pm 0.10^{\mathrm{a}}$ & $8.16 \pm 0.15^{\text {defgh }}$ & $16.15 \pm 3.42^{\mathrm{de}}$ \\
\hline L. racemosa & $16.47 \pm 0.52^{\mathrm{a}}$ & $11.21 \pm 1.60^{\text {cde }}$ & $31.92 \pm 9.69^{\mathrm{bc}}$ \\
\hline M. candidum & $5.85 \pm 3.21^{d}$ & $22.44 \pm 0.42^{\mathrm{a}}$ & $30.93 \pm 2.00^{\mathrm{bc}}$ \\
\hline M. citrifolia & $15.83 \pm 0.63^{\mathrm{a}}$ & $15.76 \pm 5.72^{\mathrm{bc}}$ & $7.36 \pm 0.65^{e f}$ \\
\hline N. fruticans & $15.51 \pm 0.48^{\mathrm{a}}$ & $6.57 \pm 2.04^{\mathrm{efgh}}$ & $1.61 \pm 0.70^{f}$ \\
\hline P. odoratatissima & $17.16 \pm 2.58^{\mathrm{a}}$ & $3.73 \pm 0.27^{\mathrm{h}}$ & $2.66 \pm 0.43^{f}$ \\
\hline P. pinnata & $13.66 \pm 1.06^{\mathrm{ab}}$ & $4.98 \pm 0.23^{\mathrm{gh}}$ & $22.72 \pm 0.54^{c d}$ \\
\hline S. hydrophyllacea & $15.08 \pm 0.14^{\mathrm{ab}}$ & $10.84 \pm 0.42^{\text {cdef }}$ & $6.41 \pm 0.52^{\text {ef }}$ \\
\hline S. portulacastrum & $11.32 \pm 1.16^{\mathrm{bc}}$ & $7.28 \pm 1.49^{\text {defgh }}$ & $4.63 \pm 0.27^{f}$ \\
\hline S. jamaicensis & $14.79 \pm 0.27^{\mathrm{ab}}$ & $11.04 \pm 0.21^{\text {cdef }}$ & $5.20 \pm 0.70^{\text {ef }}$ \\
\hline T. catappa & $14.54 \pm 1.81^{\mathrm{ab}}$ & $11.92 \pm 0.45^{\mathrm{bcd}}$ & $32.05 \pm 1.58^{\mathrm{bc}}$ \\
\hline
\end{tabular}

Data are expressed as Mean $\pm S D(n=3-6)$, means by the same superscript were not significantly different from each other $(p<0.05)$ by Fisher's LSD

ash content. The protein content in $A$. auriculiformis fruit $\left(43.88 \mathrm{mg} \mathrm{g}^{-1}\right)$ was the highest compared to other fruits, with the lowest content being that of $M$. candidum $\left(3.07 \mathrm{mg} \mathrm{g}^{-1}\right)$ in Table 1.

P. pinnata showed the highest fat content (26.45 $\left.\mathrm{mg} \mathrm{g}^{-1}\right)$, followed by $A$. auriculiformis $\left(8.77 \mathrm{mg} \mathrm{g}^{-1}\right)$, while the lowest value was found in B. asiatica $\left(1.17 \mathrm{mg} \mathrm{g}^{-1}\right)$. Similarly, P. odoratissima $\left(23.43 \mathrm{mg} \mathrm{g}^{-1}\right)$ had the highest total sugar content significantly among other fruits (Table 1). The highest reducing sugar content was found in the fruit of $M$. citrifolia $\left(18.23 \mathrm{mg} \mathrm{g}^{-1}\right.$ ) and the lowest in the fruit of $A$. auriculiformis, H. tiliaceus, L. littorea, M. candidum, P. pinnata, S. portulacastrum and T. catappa. $\left(0.01 \mathrm{mg} \mathrm{g}^{-1}\right)$.
P. odoratatissima was found to have the highest nonreducing sugar (18.24 $\mathrm{mg} \mathrm{g}^{-1}$ ) compared to other mangrove fruits, while the fruit of $B$. asiatica significantly had the highest water content (93.13\%) and L. littorea (3.41\%) the highest ash content (Table 1).

Antioxidant analysis: To evaluate the nutritional adequacy of selected mangrove fruits, the results of ascorbic acid, beta-carotene and total phenol were subjected to an additional antioxidant analysis. The highest ascorbic acid content was found significantly in $P$. odoratissima (17.16 mg/100 g), followed by L. racemosa $(16.47 \mathrm{mg} / 100 \mathrm{~g})$, H. tiliaceus $(16.28 \mathrm{mg} / 100 \mathrm{~g}$ ) and L. littorea $(16.03 \mathrm{mg} / 100 \mathrm{~g})$, with the lowest ascorbic acid content in $M$. candidum (5.85 mg/100 g) in Table 2. 
Asian J. Plant Sci., 21 (1): 145-153, 2022

Table 3: Comparative results of macronutrients from mangrove fruits in Lubuk Kertang and Pulau Sembilan, Sumatera Utara, Indonesia

\begin{tabular}{|c|c|c|c|}
\hline \multirow[b]{2}{*}{ Species } & \multicolumn{3}{|c|}{ Macronutrients from fruits of mangrove $(\mathrm{mg} / 100 \mathrm{~g})$} \\
\hline & Sodium $(\mathrm{Na})$ & Potassium (K) & Calcium (Ca) \\
\hline A. auriculiformis & $146.66 \pm 25.16^{\mathrm{bc}}$ & $1373.33 \pm 37.85^{\text {efg }}$ & $270 \pm 0.00^{\text {efg }}$ \\
\hline B. asiatica & $43.33 \pm 5.77^{e}$ & $1983.33 \pm 41.63^{\text {bcde }}$ & $190 \pm 26.45^{\mathrm{efg}}$ \\
\hline C. equisetifolia & $43.33 \pm 5.77^{e}$ & $280 \pm 10.00^{\mathrm{h}}$ & $586.67 \pm 15.27^{c d}$ \\
\hline H. tiliaceus & $20 \pm 0.00^{\mathrm{e}}$ & $1743.33 \pm 57.73^{\text {bcde }}$ & $816.67 \pm 40.41^{c}$ \\
\hline L. littorea & $623.33 \pm 51.31^{\text {abcde }}$ & $1506.67 \pm 25.16^{\text {defg }}$ & $1066.67 \pm 11.54^{b}$ \\
\hline L. racemosa & $1113.33 \pm 45.09^{a}$ & $2266.67 \pm 41.63^{\mathrm{bcd}}$ & $1173.33 \pm 23.09^{\mathrm{ab}}$ \\
\hline M. candidum & $10 \pm 0.00^{e}$ & $760 \pm 103.92^{g h}$ & $780 \pm 182.48^{c}$ \\
\hline M. citrifolia & $70 \pm 0.00^{\text {de }}$ & $2523.33 \pm 55.07^{b}$ & $383.33 \pm 5.77^{\mathrm{de}}$ \\
\hline N. fruticans & $916.66 \pm 30.55^{\mathrm{ab}}$ & $3546.67 \pm 843.46^{a}$ & $110 \pm 0.00^{f g}$ \\
\hline P. odoratatissima & $126.66 \pm 5.77^{\text {cde }}$ & $2340 \pm 45.82^{\mathrm{bcd}}$ & $320 \pm 20.00^{\text {ef }}$ \\
\hline P. pinnata & $116.66 \pm 5.77^{\text {cde }}$ & $1736.67 \pm 58.59^{\text {bcde }}$ & $253.33 \pm 23.09^{\mathrm{efg}}$ \\
\hline S. hydrophyllacea & $706.66 \pm 11.54^{\mathrm{abcd}}$ & $1626.67 \pm 11.54^{\text {cdef }}$ & $136.67 \pm 20.81^{\mathrm{fg}}$ \\
\hline S. portulacastrum & $1066.66 \pm 228.54^{a}$ & $2380 \pm 45.82^{\mathrm{bc}}$ & $430 \pm 0.00^{\text {de }}$ \\
\hline S. jamaicensis & $720 \pm 615.06^{\mathrm{abc}}$ & $1900 \pm 633.79^{\text {bcde }}$ & $1416.67 \pm 249.86^{a}$ \\
\hline T. catappa & $116.66 \pm 30.55^{\text {cde }}$ & $816.67 \pm 217.79^{f g h}$ & $63.33 \pm 11.54^{\mathrm{g}}$ \\
\hline
\end{tabular}

Data are expressed as Mean $\pm S D(n=3)$, means by the same superscript were not significantly different from each other $(p<0.05)$ with Fisher's LSD

Table 4: Comparative results of micronutrients from mangrove fruits in Lubuk Kertang and Pulau Sembilan, Sumatera Utara Indonesia

\begin{tabular}{|c|c|c|c|}
\hline \multirow[b]{2}{*}{ Species } & \multicolumn{3}{|c|}{ Macronutrients from fruits of mangrove $(\mathrm{mg} / 100 \mathrm{~g})$} \\
\hline & Iron $(\mathrm{Fe})$ & Manganese (Mn) & Copper (Cu) \\
\hline A. auriculiformis & $8.77 \pm 6.01^{\mathrm{ab}}$ & $0.87 \pm 0.15^{\text {ef }}$ & $0.12 \pm 0.02^{\mathrm{ef}}$ \\
\hline B. asiatica & $7.46 \pm 3.29^{\mathrm{ab}}$ & $0.44 \pm 0.14^{e f}$ & $0.36 \pm 0.04^{c d}$ \\
\hline C. equisetifolia & $7.07 \pm 2.34^{\mathrm{ab}}$ & $2.04 \pm 0.05^{\text {de }}$ & $0.01 \pm 0.00^{f}$ \\
\hline H. tiliaceus & $6.74 \pm 0.58^{\mathrm{ab}}$ & $19.95 \pm 1.97^{\mathrm{a}}$ & $0.73 \pm 0.05^{\mathrm{a}}$ \\
\hline L. littorea & $3.33 \pm 0.63^{b}$ & $1.09 \pm 0.16^{\text {def }}$ & $0.26 \pm 0.01^{\text {de }}$ \\
\hline L. racemosa & $5.91 \pm 0.68^{b}$ & $0.50 \pm 0.06^{\mathrm{ef}}$ & $0.42 \pm 0.04^{\mathrm{bcd}}$ \\
\hline M. candidum & $7.16 \pm 5.97^{\mathrm{ab}}$ & $7.75 \pm 0.74^{c}$ & $0.35 \pm 0.15^{c d}$ \\
\hline M. citrifolia & $6.54 \pm 1.73^{b}$ & $0.84 \pm 0.05^{\mathrm{ef}}$ & $0.01 \pm 0.00^{f}$ \\
\hline N. fruticans & $11.03 \pm 7.48^{\mathrm{ab}}$ & $13.34 \pm 0.35^{b}$ & $0.01 \pm 0.00^{f}$ \\
\hline P. odoratatissima & $5.16 \pm 1.93^{b}$ & $0.01 \pm 0.00^{f}$ & $0.02 \pm 0.01^{f}$ \\
\hline P. pinnata & $8.71 \pm 2.28^{\mathrm{ab}}$ & $1.20 \pm 0.12^{\mathrm{def}}$ & $0.44 \pm 0.16^{\mathrm{bcd}}$ \\
\hline S. hydrophyllacea & $5.32 \pm 0.27^{b}$ & $0.10 \pm 0.06^{f}$ & $0.61 \pm 0.03^{\mathrm{ab}}$ \\
\hline S. portulacastrum & $16.52 \pm 0.53^{a}$ & $2.67 \pm 0.17^{d}$ & $0.01 \pm 0.00^{f}$ \\
\hline S. jamaicensis & $6.83 \pm 1.30^{\mathrm{ab}}$ & $0.47 \pm 0.11^{\mathrm{ef}}$ & $0.47 \pm 0.07^{b c}$ \\
\hline T. catappa & $5.37 \pm 1.66^{\mathrm{b}}$ & $0.01 \pm 0.00^{f}$ & $0.26 \pm 0.01^{\mathrm{de}}$ \\
\hline
\end{tabular}

Data are expressed as Mean $\pm S D(n=3)$, means by the same superscript were not significantly different from each other $(p<0.05)$ with Fisher's LSD

Elemental analysis: The highest sodium content was in L. racemosa $(1113.33 \mathrm{mg} / 100 \mathrm{~g})$, while the minimum amount was found in $M$. candidum (10 mg/100 g). The highest Potassium content was significant in N. fruticans (3546.67 $\mathrm{mg} / 100 \mathrm{~g}$ ) and C. equisetofolia (280 mg/100 g) indicating lower potassium content. Similarly, the highest calcium content was in $S$. jamaicensis $(1416.67 \mathrm{mg} / 100 \mathrm{~g})$ and the lowest in $T$. catappa $(63.33 \mathrm{mg} / 100 \mathrm{~g})$ in Table 3. The maximum iron content was shown in $S$. portulacastrum $(16.52 \mathrm{mg} / 100 \mathrm{~g})$, while the lowest was in L. littorea ( $3.33 \mathrm{mg} / 100 \mathrm{~g})$. The $H$. tiliaceus was recorded as having the highest manganese content $(19.95 \mathrm{mg} / 100 \mathrm{~g})$, while P. odoratissima and $T$. catappa showed the lowest yields $\left(0,001 \mathrm{mg} \mathrm{g}^{-1}\right)$, respectively). Among the fifteen mangroves studied, the maximum copper content was found in $H$. tiliaceus fruits $(0.73 \mathrm{mg} / 100 \mathrm{~g})$ in Table 4.

\section{DISCUSSION}

The contents of nutrients, antioxidants macronutrients and micronutrients (element content) from mangrove fruits in Lubuk Kertang Village and Pulau Sembilan, North Sumatera, Indonesia were analyzed. Among them, $A$. auriculiformis and $P$. odoratissima were promising sources of nutrition and antioxidants. Mangroves are known to have various metabolites that are antibacterial and antifungal ${ }^{18}$, antifeedant ${ }^{19}$ and antiplasmodial ${ }^{20}$.

Antioxidants produced by the mangrove plant A. auriculiformis were identified as essential compounds for humans and beneficial for animal health ${ }^{6}$. Among these is the role of phenolics that can be used from $A$. auriculiformis as an antioxidant supplement formulation preparation ${ }^{21}$. The seeds of the acacia plant have considerable amounts of 
protein and nutritionists have shown great interest in assessing the protein quality and functionality of this protein-rich plant $^{22}$. Two new glucosides named proacaciaside I and II which show anti-filarial activity was detected in $A$. auriculiformis mangrove fruit ${ }^{22}$.

These results indicate the potential for mangrove fruits in Lubuk Kertang Village and Pulau Sembilan. These types of mangrove fruits play an important role in the food security and nutrition of rural communities in general and particularly in coastal communities ${ }^{23}$. Mangroves are rich in the nutrients required by the surrounding community and many are not known by rural communities, such that common fruit cultivars are less well known and thus inaccessible to them.

Therefore, exploration of the types of edible mangrove fruit that are less known to the public is very necessary, considering the increasing human population and diminishing natural resources. Although mangroves are rich in nutrients and antioxidants, many urban communities are still not familiar with them, and information is still limited, with their nutritional aspects and values scarce or insufficient. Edible mangrove fruit is a natural source of antioxidants. For example, $N$. fruticans was found to produce high yields of sugar saps, and it was further found to be fermented to ethanol in high yields, also as competitive as sugarcane and cone, based on the development of natural potential ${ }^{24}$. Flour from Nipah fruit had low-fat content and high crude fibre content and promising substitute for ordinary flours such as wheat rice especially for producing high fibre food ${ }^{25}$.

This study showed that $P$. odoratissima fruit is a potential source of vitamin $C$ or ascorbic acid. Vitamin C acts as a strong antioxidant that can protect cells from cancer-causing agents, and in particular, can increase the body's absorption of calcium (a mineral for the growth of teeth and bones) and iron from other foods ${ }^{26}$. The $B$. asiatica fruit showed the highest phenolic acid content. Phenolic compounds are important for products, possessing many health benefits such as antioxidant, anticarcinogenic and antimicrobial properties ${ }^{27}$.

The nutritional content, as antioxidants, macronutrients and micronutrients were selected from mangrove fruits in Lubuk Kertang dan Pulau Sembilan, North Sumatera, Indonesia was described. Among them N. fruticans, $P$. pinnata and $P$. odoratatissima were promising sources for nutritional values and antioxidants content. This study nutritional values were almost similar values with the previous studies ${ }^{28-30}$. This study provided much higher value than that reported in Carita, Banten ${ }^{31}$ for protein content in P. pinnata.
The highest protein content in the fruits of Acacia spp. in this study was supported by a previous document in $A$. tortilis ${ }^{31}$ but was higher than the protein content determined for $A$. colei and $A$. tumida $a^{32}$. Furthermore, the protein and moisture value in T. catappa and M. citrifolia was similar to those plants reported ${ }^{33,34}$. The results indicated that Acacia seed, T. catappa and M. citrifolia can be included in food formulations as a source of protein. Such as fruit consumption for Acacia spp., supporting food resources for Lubuk Kertang and Pulau Sembilan communities.

\section{CONCLUSION}

Bioprospection of fifteen mangrove plants, namely A. auriculiformis, B. asiatica, C. equisetofolia, H. tiliaceus, L. littorea, L. racemosa, M. candidum, M. citrifolia, N. fruticans, P. odoratissima, P. pinnata, S. hydrophyllacea, S. portulacstrum, $S$. jamaicensis and T. catappa has been discussed in this study. Species $A$. auriculiformis had the highest protein content of $43.88 \mathrm{mg} \mathrm{g}^{-1}$. Further, $P$. pinnata species had the highest fat content of $26.45 \mathrm{mg} \mathrm{g}^{-1}$. The total sugar content $\left(23.43 \mathrm{mg} \mathrm{g}^{-1}\right)$, non-reducing sugar (18.24 $\mathrm{mg} \mathrm{g}^{-1}$ ) and ascorbic acid from P. odoratissima species were the highest, followed by the maximum phenolic acid content identified in B. asiatica (103.69 $\mathrm{mg} \mathrm{g}^{-1}$ ). The highest content of beta carotene compounds was in $M$. candidum $22.44 \mathrm{mg} / 100 \mathrm{~g}$. From the results of the study, it is expected that these mangrove species provide potential as antioxidants, bio-nutrients and food alternatives.

\section{SIGNIFICANCE STATEMENT}

The study found that there was mangroves fruit that has good prospecting value for antioxidants and bio-nutrients and is an alternative food source too for coastal communities. This finding is expected to help researchers to find mangrove fruits provide food resources for Lubuk Kertang and Pulau Sembilan coastal communities. Thus the new finding may be considered as an alternative of food resources except conventional food resources to support coastal communities' food sources in the adjacent mangrove ecosystem.

\section{ACKNOWLEDGMENT}

This work was supported by the Ministry of Education, Culture, Research and Technology of the Republic of Indonesia through the World-Class Research Program 2021 (No. 214/SP2H/AMD/LT/DRPM/2020). 


\section{REFERENCES}

1. Biswas, S.R., M.S.I. Khan and A.U. Mallik, 2012. Invaders control on post-disturbance succession in coastal mangroves. J. Plant Ecol., 5: 157-166.

2. Tomlinson, P.B., 2016. The Botany of Mangroves. 2nd Edn., Cambridge University Press, UK., ISBN: 9781139946575.

3. Spalding, M., 2010. World Atlas of Mangroves. 1st Edn., Routledge, London, UK, Pages: 336.

4. Basyuni, M., H. Oku, E. Tsujimoto, K. Kinjo, S. Baba and K. Takara, 2007. Triterpene synthases from the Okinawan mangrove tribe,Rhizophoraceae. FEBS J., 274: 5028-5042.

5. Vinoth, R., S. Kumaravel and R. Ranganathan, 2019. Therapeutic and traditional uses of mangrove plants. J. Drug Delivery Ther., 9: 849-854.

6. Bandaranayake, W.M., 2002. Bioactivities, bioactive compounds and chemical constituents of mangrove plants. Wetlands Ecol. Manage., 10: 421-452.

7. Agoramoorthy, G., F.A. Chen, V. Venkatesalu, D.H. Kuo and P.C. Shea, 2008. Evaluation of antioxidant polyphenols from selected mangrove plants of India. Asian J. Chem., 20: 1311-1322.

8. Basyuni, M., Y.S. Siagian, B. Slamet, N. Sulistiyono, L.A.P. Putri, E. Yusraini and I. Lesmana, 2019. Leaf nutrition content and organoleptic of jeruju (Acanthus ilicifolius L) and processed products in LubukKertang village, north Sumatera. IOP Conf. Ser.: Earth Environ. Sci., Vol. 374. 10.1088/17551315/374/1/012052.

9. Darniadi, S., I. Ifie, P. Ho and B.S. Murray, 2019. Evaluation of total monomeric anthocyanin, total phenolic content and individual anthocyanins of foam-mat freeze-dried and spray-dried blueberry powder. J. Food Meas. Charact., 13: 1599-1606.

10. Basyuni, M., Y.S. Siagian, R. Wati, L.A.P. Putri, E. Yusraini and I. Lesmana, 2019. Fruit nutrition content, hedonic test, and processed products of pidada (Sonneratiacaseolaris). IOP Conf. Ser.: Earth Environ. Sci., Vol. 251. 10.1088/17551315/251/1/012042.

11. Rejeki, S., A.O. Debrot, A.M. den Brink, R.W. Ariyati and L.L. Widowati, 2020. Increased production of green mussels (Pernaviridis) using longline culture and an economic comparison with stake culture on the north coast of Java, Indonesia. Aquacult. Res., 52: 373-380.

12. Vranova, E., S. Atichartpongkul, R. Villarroel, M. Van Montagu, D. Inze and W. Van Camp, 2002. Comprehensive analysis of gene expression in Nicotianatabacum leaves acclimated to oxidative stress. Proc. Natl. Acad. Sci. USA., 99: 10870-10875.

13. Sumardi, S., M. Basyuni and R. Wati, 2018. Antimicrobial activity of polyisoprenoids of sixteen mangrove species from North Sumatra, Indonesia. Biodiversitas J. Biol. Diversity, 19: $1243-1248$.
14. Elgailani, I.E.H., M.A.M.G. Elkareem, E.A.A. Noh, O.E.A. Adam and A.M.A. Alghamdi, 2017. Comparison of two methods for the determination of vitamin c (ascorbic acid) in some fruits. Am. J. Chem., Vol. 2. 10.20448/812.2.1.1.7.

15. de Carvalho, L.M.J., P.B. Gomes, R.L.D.O. Godoy, S. Pacheco and P.H.F. do Monte et al., 2012. Total carotenoid content, $\alpha$-carotene and $\beta$-carotene, of landrace pumpkins (Cucurbita moschataDuch): A preliminary study. Food Res. Int., 47: 337-340.

16. Sari, D.P., M. Basyuni, P.A.Z. Hasibuan, S. Sumardi, A. Nuryawan and R. Wati, 2018. Cytotoxic and antiproliferative activity of polyisoprenoids in seventeen mangroves species against widr colon cancer cells. Asian Pac. J. cancer prev., 19: 3393-3400.

17. Rout, P., S. Singh, N. Kumar and U.C. Basak, 2015. Nutritional and antioxidant potential of some selected edible mangrove fruits of odisha coast. Int. J. Adv. Sci. Res., 1: 349-355.

18. Gowdhaman, P., K. Antonyraj and V. Annamalai, 2015. An effective approach on physical and dielectric properties of PZT-PVDF composites. Int. J. Adv. Sci. Res., 1: 322-328.

19. Jun, W., Q. Xiao, J. Xu, M.Y. Li, J.Y. Pana and M.H. Yang, 2008. Natural products from true mangrove flora: Source, chemistry and bioactivities. Nat. Prod. Rep., 25: 955-981.

20. Babuselvam, M., 2012. Scientific evaluation of aqueous extracts of fresh and dried leaves from Rhizophora mucronatalamk (rhizophoracea) in rats. Afr. J. Pharm. Pharmacol., 6: 814-817.

21. Sathya, A. and P. Siddhuraju, 2013. Protective effect of bark and empty pod extracts from Acacia auriculiformis against paracetamol intoxicated liver injury and alloxan induced type Il diabetes. Food Chem. Toxicol., 56: 162-170.

22. Adiamo, O.Q., M.E. Netzel, L.C. Hoffman and Y. Sultanbawa, 2019. Acacia seed proteins: low or high quality? A comprehensive review. Compr. Rev. Food Sci. Food Saf., 19: 21-43.

23. Zhou, Z., J. Chen, W. Gu and J.D. Gu, 2020. Biogeographic pattern of the nirs gene-targeted anammox bacterial community and composition in the northern south China sea and a coastal maipo mangrove wetland. Appl. Microbiol. Biotechnol., 104: 3167-3181.

24. Hidayat, I.W., 2015. Natural production potency of nipa (Nypa fruticans) sap as production commodity for bioethanol. Pros. Sem. Nas. Masy. Biodiv. Indon., 1: 109-113.

25. Sumartini, S., K.S. Harahap and A. Mujiyanti, 2020. Brownies from mangrove fruit flour: the use of variation of flours as an alternative to high food nutrition. Indonesian Food Nutr. Prog., 17: 16-22.

26. Arrigoni, O. and M.C. De Tullio, 2002. Ascorbic acid: Much more than just an antioxidant. Biochimica et Biophysica Acta (BBA), 1569: 1-9. 
27. Balasundram, N., K. Sundram and S. Samman, 2006. Phenolic compounds in plants and agri-industrial by-products: Antioxidant activity, occurrence and potential uses. Food Chem., 99: 191-203.

28. Sarungallo, Z.L., C.M.E. Susanti, N.I. Sinaga, D.N. Irbayanti and R.M.M. Latumahina, 2018. Kandungan gizi buah pandan laut (Pandanus tectorius park.) pada tiga tingkat kematangan. J. Aplikasi Teknologi Pangan, 7: 21-26.

29. Sum, P.C., H.E. Khoo and A. Azlan, 2013. Comparison of nutrient composition of ripe and unripe fruits of Nypa fruticans. Fruits, 68: 491-498.

30. Aminah, A., S. Supriyanto, I.Z. Siregar and A. Suryani, 2017. Kandungan minyak malapari (Pongamiapinnata (L.) pierre) dari pulau Jawa sebagai sumber bahan baku biodiesel. J. Penelitian Hasil Hutan, 35: 255-262.
31. Embaby, H.E. and A.M. Rayan, 2016. Chemical composition and nutritional evaluation of the seeds of Acacia tortilis (Forssk.) Hayne ssp. raddiana. Food Chem., 200: 62-68.

32. Falade, M.S., O. Owoyomi, C.E. Harwood and S.R.A. Adewusi, 2005. Chemical composition and starch hydrolysis of Acacia coleiand Acacia tumida seeds. Cereal Chem. J., 82: 479-484.

33. Ng, S., O. Lasekan, K.S. Muhammad, N. Hussain and R. Sulaiman, 2015. Physicochemical properties of Malaysiangrown tropical almond nuts ( Terminalia catappa). J. Food Sci. Technol., 52: 6623-6630.

34. Saah, S.A. and D. Adu-Poku, 2021. Phytochemical, proximate, and vitamin C content in Morinda citrifolia (Noni). J. Trop. Pharm. Chem., 5: 182-187. 